Article

\title{
Residents' Green Purchasing Intentions in a Developing-Country Context: Integrating PLS-SEM and MGA Methods
}

\author{
Bin Wang ${ }^{1}{ }^{(}$, Jionghua $\mathrm{Li}^{1}$, Ao Sun $\left.{ }^{2}{ }^{(}\right)$, Yongming Wang ${ }^{3, *}$ and Dianting $\mathrm{Wu}^{1, *}$ \\ 1 Faculty of Geographical Science, Beijing Normal University, Beijing 100875, China; \\ wangbinbnu2017@163.com (B.W.); lijionghua@126.com (J.L.) \\ 2 School of Geographical Science, Qinghai Normal University, Xining 810008, China; ray_suen@outlook.com \\ 3 College of Tourism, Hunan Normal University, Changsha 410081, China \\ * Correspondence: wym85727@163.com (Y.W.); wudianting@bnu.edu.cn (D.W.)
}

Received: 1 November 2019; Accepted: 16 December 2019; Published: 18 December 2019

check for updates

\begin{abstract}
This paper aims to examine the determinants of green purchasing intentions among different resident groups in a developing-country context. We first expand the theory of planned behaviour (TPB) and build a theoretical model based on green purchasing intention, including attitude, perceived behavioural control, subjective norms, environmental concern, habit, and socio-demographic characteristics (i.e., age, gender, residential area, and educational level). Following this, we collect 552 questionnaires from residents in Tianjin Municipality, China. We use partial least squares structural equation modelling (PLS-SEM) to analyse the green purchasing intention of the population sample and then employ a multi-group analysis (MGA) to explore the group differences in residents' green purchasing intention. The results show that green purchasing intention is significantly and positively influenced by attitude, perceived behavioural control, subjective norms, and environmental concern but not by habit. The relationship chain of environmental concern $\rightarrow$ subjective norms $\rightarrow$ purchasing intention is the strongest. The results of the MGA show that for residential-area groups, the relationships between attitudes, perceived behavioural control, and habits and purchasing intention differ significantly between the downtown group and the outside-the-city group. For the educational-level groups, the relationship between environmental concern and subjective norms differs significantly between the high-education group and the low-education group. Finally, these findings contribute to the literature on the TPB model on green purchasing intention and provide some suggestions for the local government and green marketers.
\end{abstract}

Keywords: green purchasing intention; extended TPB model; PLS-SEM; multi-group analysis

\section{Introduction}

Green consumption is a 'hot topic' in sustainable development discourses. A 30\% to $40 \%$ decline in environmental quality is caused by people's purchasing behaviour [1]. Ensuring sustainable consumption and production patterns is one of the 17 major goals in Transforming our World: The 2030 Agenda for Sustainable Development [2]. Developing countries with a large population and rapid economic development, such as China [3] and India [4-6], play an important role in implementing green and sustainable development. China presents a rapid increase in residents' green consumption. Green development has become one of the five development ideas consisting of innovative, coordinated, green, open, and inclusive development, formulated by the Communist Party of China. According to the Report on the Development of Green Consumption of Chinese Residents in 2017 from the National Development and Reform Commission, the number of green consumers on Ali's retail platform increased 14-fold 
from 2012 to 2015, accounting for 16\% of its active users [7]. China's green consumption will be of great significance to global green development, and it is essential to analyse the green consumption behaviour of Chinese consumers. Tianjin is one of central cities in China, geographically close to the national capital of Beijing. Tianjin plays an exemplary role in the country's green development, while green development has a direct impact on the environmental status of Beijing. The Tianjin Municipal Government has issued many documents in recent years in order to promote diverse and affordable green products and to encourage citizens to choose and purchase green energy-saving products. However, Tianjin is still in the early stages of green development, having a weak consciousness of green consumption, a mismatch between supply and demand of green products, and a lack of green lifestyles [8-11]. The study of Tianjin residents' purchasing intentions is helpful to understand the overall green purchasing behaviour of people in China's developed provinces and to provide a demonstration for the country.

The intention towards green purchasing determines the behaviour of green purchasing, which refers to the tendency of consumers to give priority to green products, as well as consumers being willing to make an effort to purchase green products. The theory of planned behaviour (TPB) provides a basic model for understanding residents' intentions and behaviour $[12,13]$ and is an effective model to explain consumers' purchasing intentions and behaviour from a psychological perspective. Since the TPB model was proposed by Ajzen in 1985, it has been widely applied worldwide and has become one of the most important theories in social psychology used to elaborate on the determinants of individual decision making. Research topics employing the TPB in existing research about green consumption address green purchasing [14], green products [15,16], green lodging [17], and green vehicles [18]. The TPB has also been shown to be effective in explaining consumers' green purchase intention or behaviour. Therefore, the TPB can be used to explore Tianjin's residents' green purchasing intentions. The model examines attitude, perceived behavioural control, and subjective norms and intentions. Additionally, the effects of the determinant factors on intention is tested by establishing a structural equation model. Ajzen (1991) pointed out that TPB could still be improved. Therefore, scholars integrate the values-belief-norm theory [17] and the normative activation theory [19] with the foundation of the TPB model. Xu et al. [18] applied the extended-TPB to predict customers' intention to purchase battery electric vehicles. Paul et al. [16] predicted green product consumption using the TPB and incorporating environmental concern. These extended-TPB models are first based on their own research questions and phenomena in order to find more influencing factors and, second, try to improve the explanatory power of the model. Hence, green purchasing intention is a complex causality chain, which is not only affected by attitude, perceived behavioural control, and subjective norms, but is also influenced by other elements such as environmental concern, environmental knowledge, and habits.

It is important to understand Tianjin residents' concerns about green development and their daily consumption habits. Firstly, the term 'environmental concern' is derived from political discourse and refers to the values, attitudes, emotions, conceptions, knowledge, and behavior associated with the environment [16]. Previous studies show that environmental concern has also become an important variable to study purchasing intention [5,20], and as a psychological factor, also affects consumers' attitudes, perceived behavioural control, and subjective norms [16]. Environmental concerns have a significant influence on purchasing intentions and are closely associated with the level of education and the publicity given to environmental protection knowledge. The local government must understand urban residents' environmental concerns and awareness to implement and promote sustainable policies and publicise environmental protection information in the future.

The habits of consumption have become a hot topic in sociology, psychology, and philosophy [21]. Purchasing intentions may be influenced by traditional culture and local customs that impel the residents to form the habits of consumption in daily life. According to the self-cognitive theory, habits serve as a reminder for residents to discipline themselves and as a guideline to decide their action or inaction [22]. An increasing number of studies have shown that habits could be considered as 
a determinant that influences residents' purchasing intention or behaviour [19,23]. Kollmuss and Agyeman [22] claimed that old habits form a strong barrier that should be not ignored in future studies on pro-environmental behaviour. Klöckner [24] suggests that habits must be incorporated in any behavioral model in order to increase its predictive ability. Therefore, the local government and green marketers must understand Tianjin residents' habits of consumption to take effective measures to bridge the gap between habits and future intentions or behaviour for future green development.

Previous literature focused on the determinants that affect green purchasing intention [25] and attempted to enrich the theoretical models of green purchasing intention [14,26]. However, the aforementioned literature has a major limitation. Most scholars focused on the green purchasing intentions of an identified population sample, but the research on differences between groups is insufficient. The concept of a reference group was first proposed by Hyman (1942). A reference group is a group in which individuals refer and compare themselves to others when making purchasing or consumption decisions [27]. Such a group can also have an impact on the individual's attitude towards purchasing intention, perceived behavioural control, subjective norms, environmental concern, and habits. Many studies have begun to incorporate socio-demographic characteristics into the model with the aim of exploring group differences [28-30]. Therefore, this paper attempts to incorporate socio-demographic characteristics into the extended TPB model. By exploring the influencing factors of Tianjin's residents' overall purchasing intentions, this paper compares the group differences in green purchasing intention.

In order to understand the group differences in Tianjin residents' green purchasing intentions, this paper attempts to combine the partial least squares structural equation model with the multi-group analysis (MGA) method. This paper provides some contributions to previous research. First, the partial least squares structural equation model can effectively test the determinant factors that affect the green purchasing intention of the Tianjin residents' population sample, and it can also analyse whether the green purchasing intention model is suitable for the current development stage in China. Second, an MGA can efficiently explore multi-agent purchasing intentions. This deepens the structural equation model analysis in order to explore the green purchasing intentions of different groups of residents. The combination of the partial least squares structural equation model and the MGA can compensate for the defect of population sample analyses and can find the characteristics of different groups. Additionally, this paper can provide support for future research on green purchasing intention, reference suggestions for relevant departments in the Tianjin Municipal Government, and information for green marketers.

The following paper has six sections. Following the introduction, the second section describes the extended TPB model, which includes attitude, perceived behavioural control, subjective norms, habits, environmental concern, and socio-demographic characteristics, and finally puts forward the theoretical model and hypotheses. The third section introduces the scale design, data collection, and data analysis methods. The fourth and fifth sections present and discuss the empirical results, while the last section concludes this paper.

\section{Literature Review}

The extended theory of planned behaviour model consists of three parts: Part 1 is the original TPB model, which includes attitudes toward green purchasing, perceived behavioural control, subjective norms, and green purchasing intention. Part 2 is the extended part of the TPB model, which includes environmental concern and habits. Part 3 comprises socio-demographic characteristics such as gender, age, educational level, and residential area. Finally, the theoretical model and hypotheses about Tianjin residents' green purchasing intentions are constructed.

\subsection{Attitude}

The attitude component of behavioural intention refers to the degree to which a person has a favourable or unfavourable evaluation or appraisal of the behaviour in question' [12]. Attitudes 
towards intention contain positive-bad, useful-harmful, pleasant-unhappy, and pleasing-nasty variations. According to the TPB theoretical analysis framework, attitude is one of the main predictors of behavioural intention. In the literature on pro-environment behaviour including e-waste recycling $[4,31]$ and dealing with plastic waste [32], many studies showed that intention is positively affected by attitude. Especially in studies on green consumption, scholars found the relationship between attitude and intention to be significantly positive. This includes the intention to purchase battery electric vehicles [18], energy-saving appliances [20], and organic foods [33]. Afroz et al. [34] found that attitude has a positive effect on consumers' purchasing intentions towards environmentally friendly vehicles. Similarly, Chu [33] found that a more positive attitude on the part of consumers towards organic foods could further reinforce their purchasing intentions. The attitude towards purchasing intentions reflects an individual's inner values, which guide the individual's understanding of an item and whether to buy or to continue to buy that item in the future.

Based on the above research review, the more positive the individual's attitude towards green purchasing, the stronger is the behavioural intention. Therefore, we put forward the following hypothesis:

Hypothesis 1. Attitude is positively related to green purchasing intention.

\subsection{Perceived Behavioural Control}

Perceived behavioural control regarding behavioural intention refers to 'the perceived ease or difficulty of performing the behaviour, and it is assumed to reflect past experience as well as anticipated impediments and obstacles' [12]. Perceived behavioural control consists of a sense of control and self-efficacy. The former mainly refers to consumers' evaluation of whether they can complete the purchasing task or not and it comprises internal control factors [35]. The latter is the evaluation of the purchasing process's difficulty and emphasises external and general factors [36]. When consumers prepare to purchase a green product, they could consider the accessibility, convenience, and categories of the product [16]. If fewer types of products are available or if the shopping is inconvenient or a waste of time, consumers will find it difficult to make a green purchase. Perceived behavioural control as a key variable usually had a positive influence on intention in other studies [37,38]. Wang et al. [37] found that perceived behavioural control positively influenced sustainable consumption intentions and behaviours of rural residents in China. Likewise, Paul et al. [16] discovered that there was a positive relationship between perceived behavioural control and purchasing intention.

Based on the above studies, it is clear that perceived behavioural control affects the intention to purchase green products. The stronger the perceived behavioural control, the stronger the behavioural intention. Therefore, the following hypothesis will be put forward:

Hypothesis 2. Perceived behavioural control is positively related to green purchasing intention.

\subsection{Subjective Norms}

The concept of subjective norms regarding behavioural intention refers to 'the perceived social pressure to perform or not to perform the behaviour' [12]. An individual often takes the opinions of important people around him or her as a reference. Furthermore, an individual will behave in a specific way based on perceived social pressure to perform or not to perform the behaviour. Social pressure could stem from laws, regulations, and incentive policies, which could also influence the individual's behavioural intention. Based on the TPB model, subjective norms are effective predictor variables of behavioural intention. Several researchers have proven the positive influence of subjective norms on pro-environmental behaviour. Afroz et al. [34] found that subjective norms significantly affected consumer purchase intention towards environmentally friendly vehicles. Xu et al. [18] found that subjective norms had a significantly positive influence on customers' intentions for purchasing 
battery electric vehicles in China's Zhejiang Province. Additionally, many studies have proven that the relationship is positive between subjective norms and environmental consumption intentions.

According to the above literature, we find the higher the subjective norm, the stronger the behavioural intention. Subjective norms as the main variables can explain and predict residents' intentions to purchase green products [39-41]. Therefore, this hypothesis will be put forward:

Hypothesis 3. Subjective norms are positively related to green purchasing intention.

\subsection{Environmental Concern}

Environmental concern is defined as 'the degree to which people are aware of problems regarding the environment and support efforts to solve them and or indicate the willingness to contribute personally to their solution' [16]. Environmental concern has usually been defined as a general value orientation toward the environment [42] and has proven to be a significant facilitator of pro-environmental behaviour [43]. Some studies have associated environmental concern with the intention of green purchasing [44]. Hu et al. [45] found general environmental concern as a construct used to measure green purchasing. Similarly, Yadav et al. [15] added environmental concern to the foundation of the TPB and discovered that concern affected attitude and further influenced intention. Consumers who show more interest in environmental issues or have higher environmental awareness are more willing to consume or purchase green products [46].

Furthermore, environmental concern influences attitude, subjective norms, and perceived behavioural control. Teksoz et al. [47] found environmental concern to hold significant association with people's attitudes toward the environment and outdoor activities. Hartmann and Apaolaza-Ibáñez [48] also advocated the direct and indirect effects of environmental concern, indicating that it has a positive effect on attitude and purchasing intention towards green energy brands. Environmental problems have a negative impact on people's production and life, which have become 'bottlenecks' for social progress. Hence, environmental concern is considered to be a key factor that could influence people's norms and could indirectly affect individuals' green consumption. In addition, residents consider their own abilities and conditions about carrying out pro-environmental behaviour; hence, environmental concern could affect the intention toward green consumption through perceived behavioural control. Therefore, we hypothesise that:

Hypothesis 4. Environmental concern is positively related to attitude toward the purchasing of green products.

Hypothesis 5. Environmental concern is positively related to perceived behavioural control.

Hypothesis 6. Environmental concern is positively related to subjective norms.

Hypothesis 7. Environmental concern is positively related to green purchasing intention.

\subsection{Habit}

Previous studies have indicated that an individual's past behaviour as a 'habit' had an independent influence on residents' intentions and subsequent behaviour $[49,50]$. Through the investigation of residents' habits in purchasing green products, a difference could be found between past habitual behaviour and future purchasing intention. Residents who have formed a habit continue to maintain a higher purchasing intention. In other words, the daily consumption of green products produces a kind of behavioural inertia, and the consumer will continue to purchase green products in the future. If residents do not develop habits, they will make a choice between purchasing green products or maintaining their original consumption habits. Some studies found that habits and past behaviour guided individuals' preferences and affected individuals' purchasing behaviour [51,52]. Therefore, 
the residents' habits could affect their intentions to purchase green products and their subsequent behaviour. Habit is an important element in residents' consumption intentions [53]. Therefore, we hypothesise that:

Hypothesis 8. Habit is positively related to green purchasing intention.

\subsection{Socio-Demographic Characteristics}

Previous studies have suggested that demographic variables should be considered in an analysis of consumers' behaviour. The main socio-demographic variables include age, gender, race, culture, and the like. Busse and Menzel [54] analysed adolescents' willingness to engage in pro-environment behaviour in a comparison between Germany and developing countries. Mi et al. [28] compared low-carbon consumption in different groups, including factors such as gender, marriage, educational level, age, and income. Additionally, many studies have considered socio-demographic variables to be key factors in individuals' behaviour [55-57].

Therefore, gender, age, educational level, and residential area will be considered as the main elements of this study. By classifying and analysing different groups according to the criteria of socio-demographic characteristics, the influence of different groups' attitudes, subjective norms, perceived behavioural control, environmental concern, and habits in terms of green purchasing intention can be compared. Finally, conceptual model and hypotheses on purchasing intention are established (Figure 1).

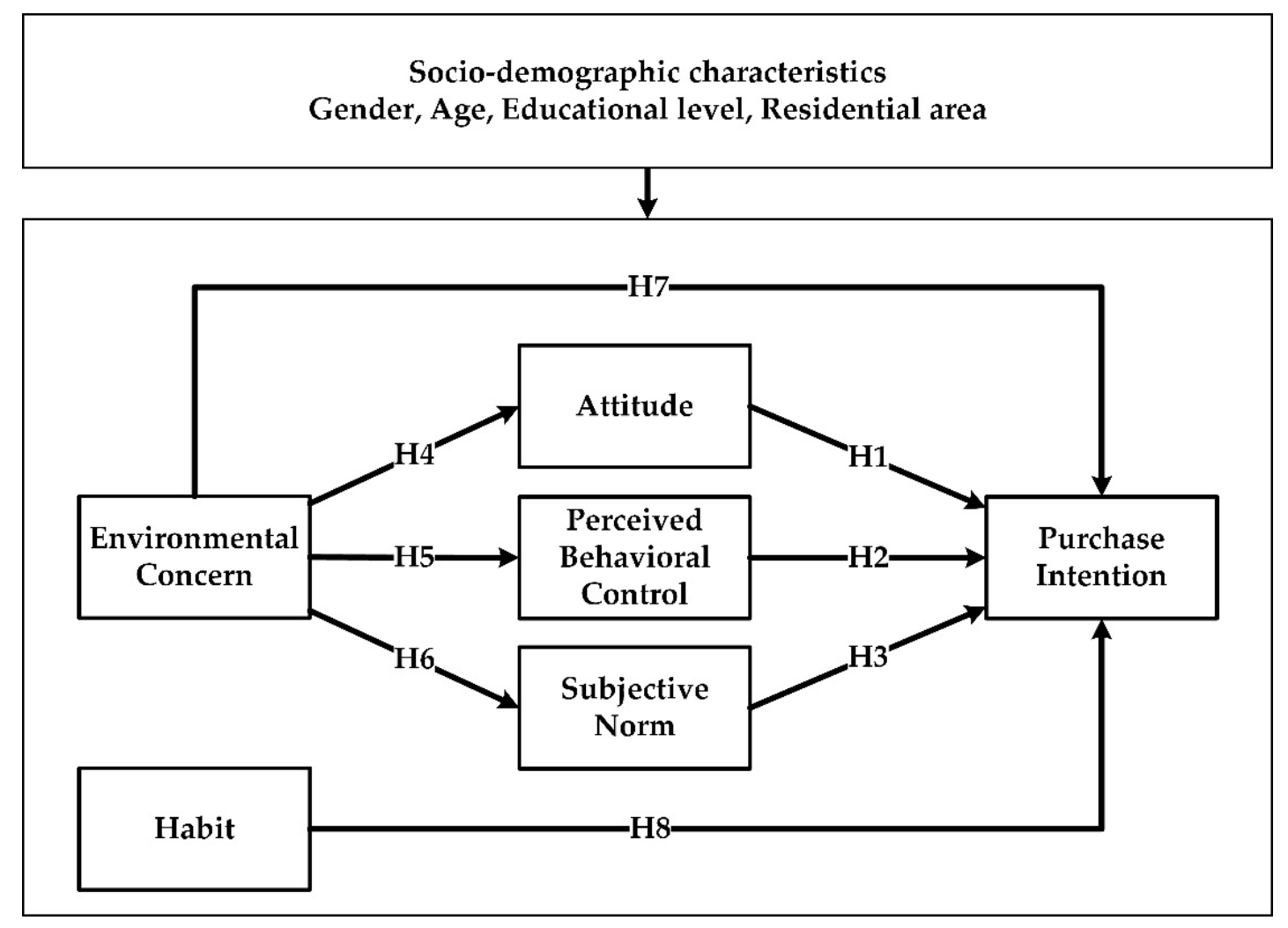

Figure 1. Conceptual model and hypotheses. 


\section{Materials and Methods}

\subsection{Questionnaire Design}

The questionnaire was designed according to previous literature and self-developed measurements. This questionnaire was divided into three sections. Section 1 contained the items about attitude, perceived behavioural control, subjective norms, and purchasing intention. The respondents indicated their agreement with each statement on a five-point Likert scale, ranging from 1 (strongly disagree) to 5 (strongly agree). Section 2 included items on habits and environmental concern. The scale of habits is measured by self-reported statements about activities in the past using a five-point Likert scale ranging from 1 (never) to 5 (always). Section 3 contained detailed information regarding socio-demographic characteristics. The questionnaire covered basic information, including gender, age, educational level, residential area, length of residence, and average monthly household income (see Appendix A).

\subsection{Data Collection}

The questionnaire aimed to investigate the green purchase intentions of residents living in Tianjin. There are 16 districts in Tianjin, and the respondents were asked to identify where they live within the municipality. A pilot study with the interview method was conducted with 45 residents selected from 6 core districts (Heping, Hexi, Hedong, Nankai, Hongqiao, Hebei) in Tianjin in May 2017. To ensure the research subjects cover the whole districts of Tianjin, based on the pilot survey and experts' advice, a professional online platform Wenjuanxing was used to support questionnaire surveys, evaluations and statistics to acquire a wide range of sample data $[18,33]$. The web-based sample is usually from people who are young, educated, wealthy, and living in the cities, and is naturally unrepresentative of the whole population [33]. However, such groups in developing counties with strong environmental awareness, constitute the powerful force in green consumption market and account for the higher proportion in green purchasers $[15,58]$. Therefore, this study also has a research significance.

Data collection occurred from September to December 2017. A total of 634 questionnaires were collected, and invalid questionnaires were excluded due to incompleteness or insincerity through data filtering. The final sample contained 552 questionnaires with a valid completion rate of $87.1 \%$. Table 1 shows the detailed information of respondents' demographic characteristics. The results show that the proportion of men and women was almost equal. Nearly half of the respondents were between the ages of 17 and $30(46.20 \%)$. The other respondents were between the ages of 31 and $45(25.18 \%)$ and 46 and $60(17.75 \%)$. The educational level of most respondents was high school or above. Nearly half of the respondents lived in the downtown area of Tianjin while others lived at a distance from the city centre. Nearly $60 \%$ of the respondents have lived in Tianjin for more than 10 years. Finally, the average monthly household income ranged 3001-6000 RMB. The income of than more than half (56.88\%) of the respondents fell into this range. The analysis of the results was based on the above samples. 
Table 1. Demographic profile of respondents $(\mathrm{N}=552)$.

\begin{tabular}{|c|c|c|}
\hline Items & Frequency & Percentage \\
\hline \multicolumn{3}{|l|}{ Gender } \\
\hline Male & 274 & $49.64 \%$ \\
\hline Female & 278 & $50.36 \%$ \\
\hline \multicolumn{3}{|l|}{ Age } \\
\hline Under 17 & 33 & $5.98 \%$ \\
\hline $17-30$ & 255 & $46.20 \%$ \\
\hline $31-45$ & 139 & $25.18 \%$ \\
\hline $46-60$ & 98 & $17.75 \%$ \\
\hline Over 60 & 27 & $4.89 \%$ \\
\hline \multicolumn{3}{|l|}{ Educational level } \\
\hline Middle school or below & 80 & $14.49 \%$ \\
\hline High school & 181 & $32.79 \%$ \\
\hline Undergraduate & 230 & $41.67 \%$ \\
\hline Postgraduate & 61 & $11.05 \%$ \\
\hline \multicolumn{3}{|l|}{ Residential area } \\
\hline Downtown & 255 & $46.20 \%$ \\
\hline Suburb & 194 & $35.14 \%$ \\
\hline Outer suburb & 64 & $11.59 \%$ \\
\hline Town & 27 & $4.89 \%$ \\
\hline Rural area & 12 & $2.17 \%$ \\
\hline \multicolumn{3}{|l|}{ Length of residence } \\
\hline Under 11 & 223 & $40.40 \%$ \\
\hline $11-20$ & 121 & $21.92 \%$ \\
\hline $21-30$ & 124 & $22.46 \%$ \\
\hline $31-40$ & 50 & $9.06 \%$ \\
\hline $41-50$ & 21 & $3.80 \%$ \\
\hline Over 50 & 13 & $2.36 \%$ \\
\hline \multicolumn{3}{|c|}{$\begin{array}{l}\text { Household Average Income (Monthly) CNY: } \\
\text { Chinese yuan. }\end{array}$} \\
\hline Under 3001CNY & 131 & $23.73 \%$ \\
\hline 3001-6000CNY & 314 & $56.88 \%$ \\
\hline 6001-10,000CNY & 93 & $16.85 \%$ \\
\hline $10,001-20,000 \mathrm{CNY}$ & 13 & $2.36 \%$ \\
\hline $20,001 \mathrm{CNY}$ or over & 1 & $0.18 \%$ \\
\hline
\end{tabular}

\subsection{Data Analysis}

Structural equation modelling was developed by Swedish statistician Karl Gustav Joreskog in the mid 1970s and was widely utilised in recent years in different fields such as psychology, economics, sociology, and others. At present, there are two kinds of estimation techniques used to solve structural equation modelling, namely covariance-based structural equation modelling (CB-SEM) and partial least squares structural equation modelling (PLS-SEM). Compared with the former, the latter has many advantages: A small sample demand; applicability to the development of the theory; suitability for prediction; and avoidance of inadmissible solutions and factor indeterminacy [59]. Therefore, PLS-SEM was used to deal with the conceptual model using SmartPLS 3.0 (SmartPLS GmbH, Hamburg, Germany).

Furthermore, PLS-SEM has the added advantage of estimating the measurement model and is suitable for conducting an MGA to analyse group differences. The MGA approach can clarify whether there are differences in hypothetical relationships among different groups. Previous studies have used the MGA for indicating groups' differences in factors such as marketing [60-62], tourism [63-65], 
and technology acceptance [66-68]. Comparing the differences between groups can be beneficial from a theoretical and practical perspective and can avoid erroneous conclusions. The overall sample was divided into groups according to criteria: (1) Gender: Male and female groups; (2) age: Young group (aged 30 and under) and elder group (aged over 30); (3) educational level: Low-education group (education in high school and below) and high-education group (college degree or above); (4) residential area: Downtown group and outside-the-city group.

\section{Results}

\subsection{Measurement Model}

Reliability and construct validity were utilised to evaluate the measurement model using a PLS analysis [69]. First, to ensure reliability, Cronbach's alpha was calculated and ranged from 0.603 to 0.809 . Hair [70] was approximately at or above the threshold value of 0.700 , but 0.600 is acceptable. Second, to examine internal consistency, composite reliability (CR) was used, which suggested that the value of CRs should be greater than 0.700 or should range above 0.800 [70]. Based on these results, we can conclude that the model is sufficiently reliable and internally consistent. Table 2 shows all factor loadings of Cronbach's $\alpha$, CRs, and average variance extracted (AVEs).

Table 2. Factor loadings, Cronbach's $\alpha$, composite reliability (CR), and average variance extracted (AVE).

\begin{tabular}{|c|c|c|c|c|c|c|c|}
\hline Constructs & Items & Factor Loading & t-Value & VIF & Cronbach's $\alpha$ & CR & AVE \\
\hline \multirow[t]{4}{*}{ Attitude } & & & & & 0.809 & 0.884 & 0.719 \\
\hline & ATT1 & 0.718 & 17.435 & 1.549 & & & \\
\hline & ATT2 & 0.910 & 70.601 & 2.519 & & & \\
\hline & ATT3 & 0.902 & 74.395 & 2.038 & & & \\
\hline \multicolumn{3}{|c|}{ Perceive behavioral Control } & & & 0.727 & 0.813 & 0.527 \\
\hline & PBC1 & 0.659 & 7.661 & 1.086 & & & \\
\hline & PBC2 & 0.860 & 15.116 & 2.175 & & & \\
\hline & РBC3 & 0.797 & 10.058 & 2.445 & & & \\
\hline & PBC4 & 0.548 & 4.282 & 1.441 & & & \\
\hline \multicolumn{2}{|c|}{ Subjective Norm } & & & & 0.681 & 0.820 & 0.606 \\
\hline & SN1 & 0.666 & 14.745 & 1.256 & & & \\
\hline & SN2 & 0.812 & 32.998 & 1.497 & & & \\
\hline & SN3 & 0.846 & 52.38 & 1.347 & & & \\
\hline \multicolumn{3}{|c|}{ Environmental Concern } & & & 0.753 & 0.835 & 0.511 \\
\hline & EC1 & 0.843 & 47.92 & 3.262 & & & \\
\hline & EC2 & 0.837 & 42.97 & 3.223 & & & \\
\hline & EC3 & 0.716 & 26.483 & 1.378 & & & \\
\hline & EC4 & 0.619 & 17.126 & 1.286 & & & \\
\hline & EC5 & 0.498 & 10.932 & 1.159 & & & \\
\hline \multirow[t]{3}{*}{ Habit } & & & & & 0.772 & 0.897 & 0.813 \\
\hline & HAB1 & 0.916 & 41.201 & 1.652 & & & \\
\hline & HAB2 & 0.888 & 30.606 & 1.652 & & & \\
\hline \multicolumn{2}{|c|}{ Purchase intention } & & & & 0.603 & 0.83 & 0.711 \\
\hline & INT1 & 0.899 & 73.122 & 1.229 & & & \\
\hline & INT2 & 0.783 & 29.685 & 1.229 & & & \\
\hline
\end{tabular}

Note: $\mathrm{CR}=$ composite reliability, $\mathrm{AVE}=$ average variance extracted.

Convergent and discriminant validities were used to test construct validity. First, convergent validity requires a factor loading of greater than 0.500 , but 0.498 was accepted as approximate to the threshold of 0.500 and was highly significant $(p<0.001)$. In addition, the average variance extracted 
(AVE) should be above 0.500 for all latent variables, which says that at least $50 \%$ of measurement variance is explained [71]. Table 2 shows that all AVEs ranged from 0.511 to 0.813 . Second, discriminant validity was examined by assessing the correlations among the measures of potentially overlapping constructs. The square root of each construct's AVE was greater than the bivariate correlation with the other constructs in the model. Table 3 shows the square roots of the AVEs and all the correlations. Additionally, the discriminant validity was tested with the Heterotrait-Monotrait (HTMT) ratio through the application of the PLS algorithm [72-74]. The HTMT method is a new technique used to evaluate discriminant validity that was established for situations when the HTMT ratio for two constructs is below 0.850 or 0.900 . It can be concluded that the results indicate adequate discriminant validity.

Table 3. Discriminant validity.

\begin{tabular}{ccccccc}
\hline & ATT & EC & HAB & INT & PBC & SN \\
\hline ATT & $\mathbf{0 . 8 4 8}$ & & & & & \\
EC & $0.355(0.427)$ & $\mathbf{0 . 7 1 5}$ & & & & \\
HAB & $0.257(0.320)$ & $0.257(0.333)$ & $\mathbf{0 . 9 0 2}$ & & & \\
INT & $0.304(0.427)$ & $0.528(0.743)$ & $0.218(0.306)$ & $\mathbf{0 . 8 4 3}$ & & \\
PBC & $0.096(0.127)$ & $0.146(0.178)$ & $0.122(0.257)$ & $0.243(0.324)$ & $\mathbf{0 . 7 2 6}$ & \\
SN & $0.216(0.291)$ & $0.436(0.594)$ & $0.120(0.171)$ & $0.583(0.834)$ & $0.081(0.181)$ & $\mathbf{0 . 7 7 8}$ \\
\hline
\end{tabular}

Note: Abbreviations: $\mathrm{ATT}=$ attitude, $\mathrm{CE}=$ environmental concern, $\mathrm{HAB}=$ habit, INT = purchase intention, $\mathrm{PBC}=$ perceived behavioral control, $\mathrm{SN}=$ subjective norm. The square roots of AVEs are shown on the diagonal in bold. The HTMT ratios are in the brackets.

\subsection{Structural Model and Hypothesis Testing}

The structural model was examined based on a collinearity assessment, the coefficient of determination $\left(R^{2}\right)$, and the path coefficient significance $(\beta)$. The full collinearity variance inflation factors (VIFs) are evaluated as an effective alternative, which can help in identifying multicollinearity issues [29]. The VIF values were below the threshold value of 3.300, signifying that collinearity is not a concern. Table 2 shows the outcome of the VIFs. The $R^{2}$ value $\left(R^{2}=0.469\right)$ indicates that $46.9 \%$ of the variance in purchasing intention can be explained from the causal relationships with the other constructs in the model; hence, this supported construct validity.

The standardised coefficient estimate points indicated that the paths between attitude and purchasing intention $(\beta 1=0.085$, $\mathrm{t}$-value $=2.311, p<0.05)$, perceived behavioural control and purchasing intention $(\beta 2=0.153$, $\mathrm{t}$-value $=4.699, p<0.001)$, and subjective norms and purchasing intention $(\beta 3=0.425$, t-value $=11.089, p<0.001)$ were significant and positive. Hence, H1, H2, and $\mathrm{H} 3$ are supported. Furthermore, environmental concern has direct and positive effects on attitude, perceived behavioural control, subjective norms, and purchasing intention $(\beta 4=0.355, \mathrm{t}$-value $=$ 9.053, $p<0.001 ; \beta 5=0.146, \mathrm{t}$-value $=3.359, p<0.001 ; \beta 6=0.436, \mathrm{t}$-value $=11.104, p<0.001$; $\beta 7=0.275$, t-value $=6.977, p<0.001$, respectively). Therefore, H4, H5, H6, and H7 are supported. However, the relationship between habit and intention to purchase green products was not significant $(\beta 8=0.056$, $\mathrm{t}$-value $=1.517, p>0.05)$; therefore, $\mathrm{H} 8$ is not supported. Table 4 shows the standardised path coefficients, $\mathrm{t}$-values, and results. 
Table 4. Results for the hypothesis model.

\begin{tabular}{cccc}
\hline Hypothesis & Path Coefficient & t-Value & Results \\
\hline H1: Attitude $\rightarrow$ Purchase intention & $0.085^{*}$ & 2.311 & Supported \\
H2: Perceived behavioral control $\rightarrow$ Purchase intention & $0.153^{* * *}$ & 4.699 & Supported \\
H3: Subjective norm $\rightarrow$ Purchase intention & $0.425^{* * *}$ & 11.089 & Supported \\
H4: Environmental concern $\rightarrow$ Attitude & $0.355^{* * *}$ & 9.053 & Supported \\
H5: Environmental concern $\rightarrow$ Perceived behavioral control & $0.146^{* * *}$ & 3.359 & Supported \\
H6: Environmental concern $\rightarrow$ Subjective norm & $0.436^{* * *}$ & 11.104 & Supported \\
H7: Environmental concern $\rightarrow$ Purchase intention & $0.275^{* * *}$ & 6.977 & Supported \\
H8: Habit $\rightarrow$ Purchase intention & 0.056 & 1.517 & No supported \\
\hline
\end{tabular}

Note: Significance level: ${ }^{*} p<0.05,{ }^{* * *} p<0.001$.

The direct effect of subjective norms on purchasing intention was higher than environmental concern, perceived behavioural control, and attitude. The effect of environmental concern on subjective norms was greater than that on attitude and perceived behavioural control. Figure 2 shows the path coefficients and degree of influence.

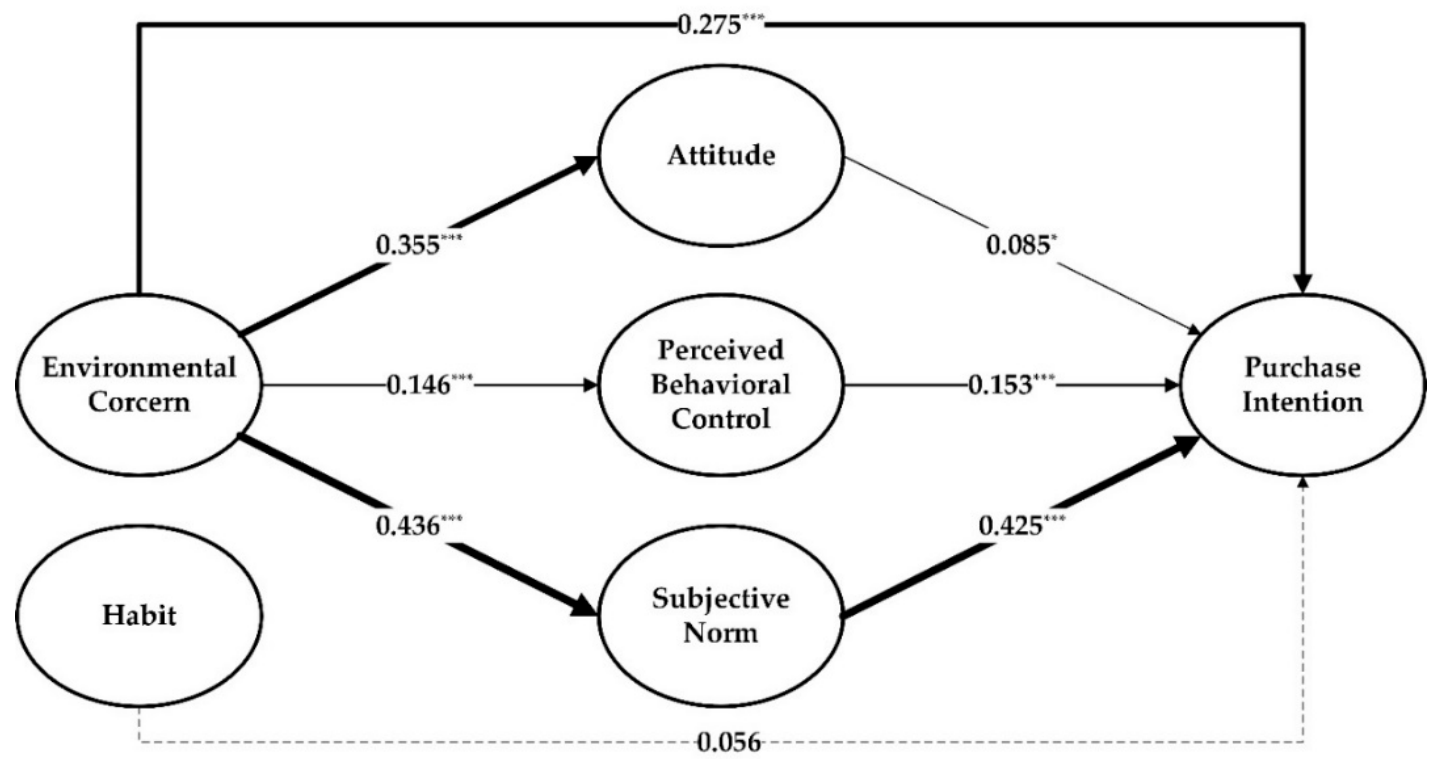

Figure 2. Structural equation model of green purchase intention. Note: Direct influence is indicated by a solid line, and the line width indicates the degree of influence; no influence is shown using a broken line. Significance level: ${ }^{*} p<0.05,{ }^{* * *} p<0.001$.

\subsection{Multi-Group Analysis}

An MGA was utilised to explore the effects of the variables among the different groups. The categorical variables available to the MGA were Age, Gender, Residential area, and Educational level. We applied a percentile bootstrapping method to examine the differences among the groups. The results indicated a significant difference among groups at the $5 \%$ error level if the $p$-value was greater than $95 \%$ or less than $5 \%$. Particularly, the percentile below $5 \%$ indicates that the bootstrapping results of group A are higher than those of group B. The percentile above $95 \%$ shows that the results of group B are higher than those of group A [75].

The estimated paths for each group are shown in Table 5. H1, which suggested a positive relationship between attitude and purchasing intention, was supported in the younger group $(\beta=0.116$, $p<0.05)$ and the downtown group $(\beta=0.168, p<0.001)$, but was not supported in the other groups. $\mathrm{H} 2$, which suggested a positive relationship between perceived behavioural control and purchasing intention, was supported in the elder group $(\beta=0.171, p<0.001)$, the outside-the-city group $(\beta=0.229$, $p<0.001$ ), the gender groups (Female: $\beta=0.176, p<0.001$; Male: $\beta=0.141, p<0.001$ ), and the 
education groups (Low: $\beta=0.130, p<0.05$; High: $\beta=0.169, p<0.001$ ). H3, which suggested a positive relationship between subjective norms and purchasing intention, was supported in all groups and the path coefficients were above 0.400 . H4, which suggested a positive relationship between environmental concern and attitude, was supported in all groups and the path coefficients were higher than 0.300 . H5, which suggested a positive relationship between environmental concern and perceived behavioural control, was supported in the elder group $(\beta=0.140, p<0.05)$, the downtown group $(\beta=0.199$, $p<0.05)$, the female group $(\beta=0.203, p<0.01)$, and the high-education group $(\beta=0.166, p<0.05)$ but was, however, not supported in the other groups. H6, which suggested a positive relationship between environmental concern and subjective norms, was supported in all groups, and the path coefficients ranged from 0.353 to 0.494 . H7, which suggested that there was a positive relationship between environmental concern and intention, was supported in all groups, and the path coefficients ranged from 0.238 to 0.317 . Habits have a significantly positive effect on purchasing intention in the younger group $(\beta=0.118, p<0.05)$ and the downtown group $(\beta=0.141, p<0.01)$, thereby supporting H8.

Table 5. Results of SEM-multi-group analysis (MGA).

\begin{tabular}{|c|c|c|c|c|c|c|c|c|}
\hline & H1 & $\mathbf{H} 2$ & H3 & $\mathbf{H} 4$ & H5 & H6 & H7 & H8 \\
\hline \multicolumn{9}{|l|}{ Age } \\
\hline Young $(n=288)$ & 0.116 * & 0.100 & $0.407^{* * *}$ & $0.335^{* * *}$ & 0.149 & $0.469^{* * *}$ & $0.282 * * *$ & 0.118 * \\
\hline Elder $(n=264)$ & 0.033 & $0.171^{* * *}$ & $0.428 * * *$ & $0.377^{* * *}$ & 0.140 * & $0.399^{* * *}$ & $0.279 * * *$ & 0.030 \\
\hline Diff. & 0.083 & 0.071 & 0.021 & 0.042 & 0.009 & 0.070 & 0.003 & 0.088 \\
\hline PLS-MGA $p$-Value & 0.135 & 0.838 & 0.619 & 0.730 & 0.432 & 0.183 & 0.485 & 0.122 \\
\hline \multicolumn{9}{|l|}{ Residential area } \\
\hline Downtown $(\mathrm{n}=271)$ & $0.168^{* * *}$ & 0.031 & $0.442^{* * *}$ & $0.316^{* * *}$ & $0.199 *$ & $0.448^{* * *}$ & $0.244^{* * *}$ & $0.141^{* *}$ \\
\hline Outside-the-city $(\mathrm{n}=281)$ & -0.011 & $0.229 * * *$ & $0.416^{* * *}$ & $0.368^{* * *}$ & 0.090 & $0.395^{* * *}$ & $0.314^{* * *}$ & -0.015 \\
\hline Diff. & 0.179 & 0.198 & 0.026 & 0.052 & 0.109 & 0.053 & 0.071 & 0.156 \\
\hline PLS-MGA $p$-Value & 0.006 & 0.992 & 0.378 & 0.766 & 0.108 & 0.248 & 0.800 & 0.014 \\
\hline \multicolumn{9}{|l|}{ Gender } \\
\hline Female $(\mathrm{n}=280)$ & 0.067 & $0.176^{* * *}$ & $0.428^{* * *}$ & $0.306^{* * *}$ & $0.203^{* *}$ & $0.389^{* * *}$ & $0.261^{* * *}$ & 0.024 \\
\hline Male $(\mathrm{n}=272)$ & $0.110 *$ & $0.141^{* * *}$ & $0.421^{* * *}$ & $0.394^{* * *}$ & 0.093 & $0.473^{* * *}$ & $0.292 * * *$ & 0.090 \\
\hline Diff. & 0.043 & 0.035 & 0.007 & 0.088 & 0.109 & 0.084 & 0.030 & 0.067 \\
\hline PLS-MGA $p$-Value & 0.732 & 0.301 & 0.465 & 0.893 & 0.115 & 0.855 & 0.641 & 0.823 \\
\hline \multicolumn{9}{|l|}{ Educational level } \\
\hline Low $(n=249)$ & 0.065 & $0.130 *$ & $0.436^{* * *}$ & $0.357^{* * *}$ & 0.146 & $0.353^{* * *}$ & $0.238^{* * *}$ & 0.094 \\
\hline $\operatorname{High}(\mathrm{n}=303)$ & 0.084 & $0.169 * * *$ & $0.408^{* * *}$ & $0.352^{* * *}$ & $0.166^{*}$ & $0.494^{* * *}$ & $0.317^{* * *}$ & 0.018 \\
\hline Diff. & 0.018 & 0.039 & 0.028 & 0.006 & 0.020 & 0.141 & 0.078 & 0.076 \\
\hline PLS-MGA $p$-Value & 0.602 & 0.692 & 0.368 & 0.469 & 0.571 & 0.968 & 0.812 & 0.147 \\
\hline
\end{tabular}

Note: Significance level of path coefficient: ${ }^{*} p<0.05,{ }^{* *}<0.01,{ }^{* * *} p<0.001$. Bold font: PLS-MGA $p$-value below $5 \%$ and above $95 \%$ indicate significant values. Diff.=Path Coefficient Differences.

The results of the PLS-MGA $p$-value showed that there were significant group differences. For the Age groups, the multi-group permutation test showed no significant difference between the younger and the elder groups. For the Residential area groups, H1 ( $p$-value $=0.006<0.05)$ differed significantly, showing a stronger relationship between attitude and purchasing intention for the downtown group in comparison to the outside-the-city group. $\mathrm{H} 2(p$-value $=0.992>0.95)$ differed significantly, meaning the relationship between perceived behavioural control and purchasing intention is stronger for the outside-the-city group in comparison to the downtown group. H8 ( $p$-value $=0.014<0.05$ ) differed significantly, showing a stronger relationship between habits and green purchasing intention for the downtown group when compared to the outside-the-city group. For the Gender groups, the multi-group permutation test showed no significant differences between females and males. For the Educational level groups, H6 ( $p$-value $=0.968>0.95$ ) differed significantly, showing a stronger relationship between environmental concern and subjective norms for the high-education group when compared to the low-education group. 


\section{Discussion}

This study aimed to discover heterogeneity in different residents' green purchasing intentions in Tianjin, China. First, this paper extended the TPB model and provided a theoretical model for green purchasing intention. After the calculation of PLS-SEM, it was found that attitude, perceived behavioural control, subjective norms, and environmental concern had a significantly positive influence on green purchasing intention in the Municipality of Tianjin, China. Second, the MGA approach was effectively applied in order to identify differences in the effects of green purchasing intention and its influencing factors among different groups. In accordance with the results of the analysis, theoretical and practical implications will be provided.

\subsection{Theoretical Implications}

\subsubsection{Theoretical Implications on the Population Sample}

First, this study enriches the current literature on green purchasing intention based on the extended TPB model. The structural equation model clearly depicted that five determinants (attitude, perceived behavioural control, subjective norms, environmental concern, and habits) explained $46.9 \%$ of the dependent variable (green purchasing intention). The explanatory power of the five potential variables regarding purchasing intention is nearly $50 \%$, which indicates that these latent variables have good explanatory power. The extended TPB model on green purchasing intention can be utilised by future researchers who can test its reliability and validity in other contexts.

Second, the relationships between intentions and attitude, perceived behavioural control, and subjective norms were examined in the overall sample. The findings showed that three of these relationships passed the significance test and supported $\mathrm{H} 1, \mathrm{H} 2$, and $\mathrm{H} 3$, which was consistent with the results of former studies by $\mathrm{Xu}$ et al. [18] and Li et al. [76]. This shows that there are significant and positive influences between the three factors and purchasing intention. That is to say, the better the attitude, perceived behavioural control, and subjective norms, the higher the intention to purchase green products. Nevertheless, when the MGA was performed, these hypotheses were not supported in some groups. In the overall sample, subjective norms had the strongest explanatory power in relation to purchasing intention, meaning that residents' purchasing intentions were affected by the external environment, especially the laws and regulations issued by the government to promote green consumption, as well as by purchase subsidies and preferential policies, and by advice from the people around them.

Third, environmental concern was added to extend the TPB model on green purchasing intention. The research's main contribution is that environmental concern was shown to have a significant and positive impact on attitude, perceived behavioural control, subjective norms, and intentions for green consumption, which is consistent with the results of previous empirical studies by Paul et al. [16], Yadav and Pathak [15]. H4, H5, H6, and H7 were supported in this study. This means that environmental concern affects purchasing intention directly and indirectly through attitude, perceived behavioural control, and subjective norms. Surprisingly, the relationship chain of environmental concern $\rightarrow$ subjective norms $\rightarrow$ purchasing intention is the strongest. Residents who are highly concerned about the health of the environment will have higher subjective norms, and this will affect their willingness to buy green products. Environmental concern can be used as an important factor for future research on green purchasing intention.

Fourth, daily habits were added, which developed the TPB model. By calculating the mean value of the indicators in the questionnaires, it was found that the average values of purchasing green appliances (HAB1) and green goods with eco-labels (HAB2) were 3.45 and 3.35, respectively. Therefore, habitual purchasing behaviour of green products is at the general level. Meanwhile, the mean values of giving priority to green products (INT1) and paying more money for green products (INT2) were 3.65 and 2.92, respectively. However, the relationship between habits and purchasing intention failed to pass the significance test. Hence, we infer that in the early stages of the green 
concept's implementation, people may not have formed the habit of buying green products and their willingness to buy these products may not be particularly high. Even if residents are willing to buy green products, they will make decisions based on the price of the product and their own income and expenditure. Therefore, a gap can be inferred between the past habits of consumption and future purchasing intentions. Namely, Tianjin's residents have not yet formed the habit of green consumption, although green consumption has become a trend of development in China. Furthermore, good habits of sustainable consumption could promote green purchasing, while bad habits may become obstacles to green consumption and sustainable policy enforcement [22]. Therefore, the government should emphasise how to guide and foster proper green habits across the whole of society. Despite the fact that habits have no significant effect on intention of green consumption in the pooled data, different results were found through the MGA approach. Additionally, habits can be important elements in comparing green buying intentions between developing and developed countries.

The extended TPB is helpful to explore more factors that influence Tianjin's residents' green purchasing intentions and to improve the model's explanatory power. By using the extended TPB, the relationships between intentions and attitude, perceived behavioural control, and subjective norms were verified as contributing to Tianjin's residents' green purchasing. The effects of environmental concern and habits toward green purchasing intentions were further examined at the current stage of green development in China. The extended TPB sheds light on the gap between past behaviour and future intentions.

\subsubsection{Theoretical Implications of the Multi-Group Analysis}

The results showed significant differences in green purchasing intention due to differences in demographic characteristics such as age, residential area, gender, and educational level. Overall, H3, $\mathrm{H} 4, \mathrm{H} 6$, and $\mathrm{H} 7$ were all supported judging by the purchasing intentions of different social groups. Next, the different groups' purchasing intentions will be discussed.

For the Age groups, besides subjective norms and environmental concern, the younger group's attitude and habits had a significantly positive impact on intention, while the elder group's perceived behavioural control had a positive effect on intention. These results show that young people in the new era may pay more attention to their quality of life and tend to buy eco-friendly products and goods in their daily lives while elders may consider the real purchasing power of the family more realistically along with some external constraints. Compared with the elder group, the younger group's environmental concerns have a stronger influence on the subjective norms, which is related to the fact that they have obtained more environmental knowledge through books, magazines, and network media [15]. Hence, young people are also inclined to develop the habit of buying green goods in their daily life.

For the Residential area groups, there were significant differences in the impact of attitudes, perceived behavioural control, and daily habits on purchasing intention between the residents of the downtown group and the outside-the-city group, because residents living in the city centre may be more informed and knowledgeable than those living at a distance from the downtown area. Many shopping malls in the downtown area are major markets for green goods, and residents of the city centre find it easier to choose and buy green goods. Residents of the city centre are more likely to develop their buying habits while residents who live at a distance from the city centre need to consider factors such as the costs of time and traffic when preparing to purchase green products. Therefore, residents living in the downtown area have a higher tendency to purchase green products.

For the Gender groups, the relationship between environmental concern and perceived behavioural control has passed the significance test for the female group, which indicates that females may pay more attention to environmental influences on society and may be more inclined to practice environmental protection behaviour. However, the male group was more rational and had a better attitude towards green products, and so may be more inclined to buy environmentally friendly products. 
For the Educational level groups, there were significant differences between environmental concern and subjective norms. The high-education group's concern for the environment is more likely to affect their subjective norms when compared to that of the low-education group. The higher education group has more environmental knowledge and shows more concern about urban environmental problems than the lower education group. A person with a higher level of education may have a better knowledge of environmental protection, understand the hazards of environmental damage, and pay more attention to environmental problems in and around the city. The amount of attention people pay to the problems of the urban environment is not only affected by people's internal education level, but also by the external environmental protection knowledge, such as the public environmental protection publicity carried out by the local government. When people choose green products, their purchasing intentions are subtly affected by environmental knowledge and concern. Thus, environmental concern and knowledge affect consumers' willingness to consume or purchase green products. Thus, environmental concern and knowledge affect consumers' willingness to consume or purchase green products.

Results of the analysis and comparison of multiple groups showed definite group differences for the green purchasing intentions among Tianjin's residents, which are consistent with the results of previous empirical studies using multi-group analyses [28,29]. Integrating PLS-SEM and MGA methods is effective because these methods can not only analyse the green purchasing behaviour of the population sample, but can also find group differences [30,77]. Additionally, this study has some practical implications.

\subsection{Practical Implications}

The practical implications of this study are as follows: On the one hand, this paper can provide suggestions for policymakers to promote the green development of cities. On the other hand, it can provide suggestions for green marketers to understand the consumer psychology of different groups and promote green marketing in the future.

\subsubsection{Practical Implications for Local Policymakers}

The results showed that subjective norms had the strongest impact on intentions of green purchasing. First, the local government plays a significant role in promoting the residents' green purchasing intentions. Residents tend to obey laws and regulations and are more concerned about the availability of subsidies. For policymakers, it is essential to enact mandatory laws and regulations to regulate pro-environment protection behaviour in residents strictly. Second, in the current stage of green consumption development, the government could introduce incentive policies to guide green consumption. This could be interesting in the context of China because it is a developing country where living standards are different from those of developed countries. Therefore, people may seek financial subsidies or rewards to participate in green consumption [32]. Finally, a person could be subject to the opinions of important people, such as family members, relatives, and friends. Therefore, communities could advocate pro-environment behaviours and green consumption in people's daily lives to create a good pro-environmental atmosphere. For policymakers, it is essential to improve residents' understanding of environmental knowledge and to raise people's awareness of green consumption through the media, slogans, and brochures.

\subsubsection{Practical Implications for Green Marketers}

These findings indicate that there are differences in green purchasing intentions among different groups. First, green marketers need to understand different groups' consumption preferences, for example, different groups' attitudes toward green consumption, such as energy-saving performance, technological content, quality, and reliability. Second, green marketers should actively promote the availability, accessibility, and information about green products. Third, green marketers need to pay attention to different regional demands, and they should design a variety of green products. It is worth noting that this paper is only a survey of residents' green purchasing intentions at a specific point in 
time. In the future, green marketers should also pay attention to the change of residents' purchasing intentions and adjust marketing strategies in a timely manner.

\subsection{Limitations and Future Research}

There are some limitations in this paper, and future research will continue to be carried out in-depth. First, this paper only focuses on the intention of green consumption in the Municipality of Tianjin; thus, we have been working with finding regional differences in green purchasing intentions. However, Tianjin, as an important city in the developing country of China, is a microcosm of China's green development. It can reflect the problems existing in China's current green development process from one side. Further studies could aim to compare the green purchasing intentions of different cities, such as first-tier cities (Beijing, Shanghai), second-tier cities (Shi Jiazhuang), and third-tier cities (Baoding, Tangshan). Second, environmental concern and habits were added into the TPB model to extend it. In the future, we will add environmental knowledge, place attachment, ascription of responsibility, and other variables to explain intentions toward green purchasing. We will further expand the TPB model and capture more information on residents' green purchasing intentions. Third, more multi-group analyses will be practised in order to explore the green purchasing intentions of more and different groups in the future. Finally, we will also give attention to the changes in Tianjin residents' green purchasing habits and willingness in the process of promoting the national green development strategy.

\section{Conclusions}

In conclusion, this paper expands the TPB model on green purchasing intentions consisting of attitude, perceived behavioural control, subjective norms, environmental concern, habits, and demographic characteristic variables. Using this extended model, 552 valid residents' questionnaires from Tianjin Municipality, China, were analysed using PLS-SEM with SmartPLS 3.0. We found that the extended TPB model has good explanatory power in terms of green purchasing intention. These findings show that green purchasing intention is significantly and positively affected by attitude, perceived behavioural control, subjective norms, and environmental concern, but not by habits as shown in the pooled data in a developing-country context. We inferred that Tianjin's residents have not yet formed a strong habit of consumption to promote green purchasing at the current stage of sustainable development. Therefore, local governments need to formulate proper policies and take appropriate measures to guide the green consumption of their constituents. Additionally, the relationship chain (environmental concern $\rightarrow$ subjective norms $\rightarrow$ purchasing intention) is strongest when compared to the other relational chains. The extended TPB enriches and develops the original model by incorporating environmental concern and habits. The extended TPB allows researchers to explore more motivation and barriers to green purchasing intentions in the undercurrent of China's green development. The final model can provide a reference for further study.

In order to understand the green purchasing intention of different groups, this paper adopts an MGA. Results indicated that heterogeneity is present in the green purchasing intention of residents. We found that the relationships between attitude, perceived behavioural control, and habits and purchasing intention differ significantly in residential-area groups. Furthermore, the relationship between environmental concern and subjective norms differed significantly in the educational groups. The MGA approach provides an effective way to understand the intentions of different groups. Finally, this study provided suggestions for the relevant government departments and green marketers.

Author Contributions: Conceptualisation, D.W., Y.W., and B.W.; formal analysis, B.W.; methodology, D.W., A.S., and J.L.; investigation, Y.W. and J.L.; software, B.W.; writing-original draft, B.W.; writing-review and editing, B.W., A.S., and Y.W. All authors have read and agreed to the published version of the manuscript.

Funding: This work was supported by the National Natural Science Foundation of China (Grant No. 41771128 and 41761023) and Geopolitical Environment and Frontier Development in Southwest China (Grant No. KJHX2018494).

Conflicts of Interest: The authors declare no conflict of interest. 


\section{Appendix A Measurement Items}

\begin{tabular}{|c|c|c|}
\hline Constructs & Measurements & References \\
\hline $\begin{array}{l}\text { Attitude towards purchasing } \\
\text { green products (ATT) }\end{array}$ & $\begin{array}{ll}- & \text { I like the idea of purchasing green products. (ATT1) } \\
- & \text { I am familiar with green products. (ATT2) } \\
- & \text { Green consumption belongs to low-carbon behaviour. (ATT3) }\end{array}$ & {$[16,18]$} \\
\hline $\begin{array}{l}\text { Perceived behavioural } \\
\text { control (PBC) }\end{array}$ & $\begin{array}{l}\text { - } \quad \text { It saves time by choosing and purchasing green and environmental } \\
\text { protection products. (PBC1) } \\
\text { - } \quad \text { A lot of people around me buy green products. (PBC2) } \\
\text { - } \quad \text { I believe I have the ability to purchase green products. (PBC3) } \\
\text { - } \quad \begin{array}{l}\text { Green products are generally available in the shops where I usually } \\
\text { do my shopping. (PBC4) }\end{array}\end{array}$ & {$[74,78]$} \\
\hline Subjective norms (SN) & $\begin{array}{l}\text { - If the local government provides subsidies, I would like to purchase } \\
\text { green products. (SN1) } \\
\text { If there are relevant legal provisions, I would like to buy green } \\
\text { products. (SN2) } \\
\text { - Most people who are important to me think I should purchase green } \\
\text { products when going for purchasing. (SN3) }\end{array}$ & {$[16,33]$} \\
\hline Environmental concern (EC) & $\begin{array}{l}\text { - } \quad \text { I will be angry seeing environmental damage in public. (EC1) } \\
\text { - } \quad \text { I will be angry seeing environmental damage in the media. (EC2) } \\
\text { I am very interested in environmental protection, green consumption } \\
\text { and other related knowledge. (EC3) } \\
\text { - } \quad \text { Each of us has an obligation to protect the ecological environment. } \\
\text { (EC4) } \\
\text { - Limited resources and environmental pollution have threatened } \\
\text { human health. (EC5) }\end{array}$ & {$[20,79-81]$} \\
\hline Habits (HAB) & $\begin{array}{ll}\text { - } & \text { I used to purchase energy-saving appliances. (HAB1) } \\
\text { - } & \text { I used to purchase goods with eco-labels. (HAB2) }\end{array}$ & {$[28,37]$} \\
\hline Purchasing intention (INT) & $\begin{array}{l}\text { - } \quad \text { I will give priority to purchasing it if a product is green. (INT1) } \\
\text { - } \quad \text { I am willing to pay more money to purchase a green product. (INT2) }\end{array}$ & {$[18,33]$} \\
\hline
\end{tabular}

\section{References}

1. Mcdougall, G.H.G. The green movement in Canada: Implications for marketing strategy. J. Int. Consum. Mark. 1993, 5, 69-87.

2. United Nations. Available online: https://www.un.org/sustainabledevelopment/sustainable-consumptionproduction/ (accessed on 5 June 2018).

3. Qi, X.; Ploeger, A. Explaining consumers' intentions towards purchasing green food in Qingdao, China: The amendment and extension of the theory of planned behavior. Appetite 2019, 133, 414-422. [CrossRef] [PubMed]

4. Dwivedy, M.; Mittal, R.K. Willingness of residents to participate in e-waste recycling in India. Environ. Dev. 2013, 6, 48-68. [CrossRef]

5. Jaiswal, D.; Kant, R. Green purchasing behaviour: A conceptual framework and empirical investigation of Indian consumers. J. Retail Consum. Serv. 2018, 41, 60-69. [CrossRef]

6. Singh, M.P.; Chakraborty, A.; Roy, M. Developing an extended theory of planned behavior model to explore circular economy readiness in manufacturing MSMEs, India. Resour. Conserv. Recy. 2018, 135, 313-322. [CrossRef]

7. China National Development and Reform Commission. Available online: http://www.ndrc.gov.cn/fzgggz/ hjbh/hjzhdt/201804/t20180404_881784.html (accessed on 4 April 2018).

8. Mostafa, M.M. A hierarchical analysis of the green consciousness of the Egyptian consumer. Psychol. Market. 2007, 24, 445-473. [CrossRef]

9. Bai, Y.; Liu, Y. An exploration of residents' low-carbon awareness and behavior in Tianjin, China. Energy Policy 2013, 61, 1261-1270. [CrossRef] 
10. Fu, L.P.; Zhang, Y.; Xiong, X.; Bai, Y. Pro-environmental awareness and behaviors on campus: Evidence from Tianjin, China. Eurasia. J. Math. Sci. T. 2018, 14, 427-445. [CrossRef]

11. Liu, D.Y.; Du, H.B.; Southworth, F.; Ma, S.F. The influence of social-psychological factors on the intention to choose low-carbon travel modes in Tianjin, China. Transport Res. A-Pol. 2017, 105, 42-53. [CrossRef]

12. Ajzen, I. The theory of planned behavior. Organ. Behav. Hum. Dec. 1991, 50, 179-211. [CrossRef]

13. Si, H.Y.; Shi, J.G.; Tang, D.Z.; Wen, S.P.; Miao, W.; Duan, K.F. Application of the theory of planned behavior in Environmental Science: A comprehensive bibliometric analysis. Int. J. Environ. Res. Public Health 2019, 16, 2788. [CrossRef] [PubMed]

14. Yadav, R.; Pathak, G.S. Determinants of consumers' green purchase behavior in a developing nation: Applying and extending the theory of planned behavior. Ecol. Econ. 2017, 134, 114-122. [CrossRef]

15. Yadav, R.; Pathak, G.S. Young consumers' intention towards buying green products in a developing nation: Extending the theory of planned behavior. J. Clean. Prod. 2016, 135, 732-739. [CrossRef]

16. Paul, J.; Modi, A.; Patel, J. Predicting green product consumption using theory of planned behavior and reasoned action. J. Retail Consum. Serv. 2016, 29, 123-134. [CrossRef]

17. Han, H. Travelers' pro-environmental behavior in a green lodging context: Converging value-belief-norm theory and the theory of planned behavior. Tourism Manag. 2015, 47, 164-177. [CrossRef]

18. Xu, Y.L.; Zhang, W.Y.; Bao, H.J.; Zhang, S.; Xiang, Y. A SEM-Neural network approach to predict customers' intention to purchase battery electric vehicles in China's Zhejiang Province. Sustainability 2019, 11, 3164. [CrossRef]

19. Gkargkavouzi, A.; Halkos, G.; Matsiori, S. Environmental behavior in a private-sphere context: Integrating theories of planned behavior and value belief norm, self-identity and habit. Resour. Conserv. Recy. 2019, 148, 145-156. [CrossRef]

20. Song, Y.; Zhao, C.N.; Zhang, M. Does haze pollution promote the consumption of energy-saving appliances in China? An empirical study based on norm activation model. Resour. Conserv. Recy. 2019, 145, 220-229.

21. Warde, A.; Southerton, D. The Habits of Consumption; Helsinki Collegium for Advanced Studies: Helsinki, Finland, 2012.

22. Kollmuss, A.; Agyeman, J. Mind the gap: Why do people act environmentally and what are the barriers to pro-environmental behavior? Environ. Educ. Res. 2002, 8, 239-260. [CrossRef]

23. Shi, D.; Wang, L.; Wang, Z.X. What affects individual energy conservation behavior: Personal habits, external conditions or values? An empirical study based on a survey of college students. Energy Policy 2019, 128, 150-161.

24. Klöckner, C.A. A comprehensive model of the psychology of environmental behaviour-A meta-analysis. Global Environ. Chang. 2013, 23, 1028-1038. [CrossRef]

25. Prakash, G.; Choudhary, S.; Kumar, A.; Garza-Reyes, J.A.; Khan, S.A.R.; Panda, T.K. Do altruistic and egoistic values influence consumers' attitudes and purchase intentions towards eco-friendly packaged products? An empirical investigation. J. Retail Consum. Serv. 2019, 50, 163-169. [CrossRef]

26. Hameed, I.; Waris, I.; ul Haq, M.A. Predicting eco-conscious consumer behavior using theory of planned behavior in Pakistan. Environ. Sci. Pollut. R. 2019, 26, 15535-15547. [CrossRef] [PubMed]

27. Hyman, H.H. The psychology of status. Arch. Psychol. (Columbia Univ.) 1942, 269, 94.

28. Mi, L.Y.; Zhu, H.L.; Yang, J.; Gan, X.L.; Xu, T.; Qiao, L.J.; Liu, Q.Y. A new perspective to promote low-carbon consumption: The influence of reference groups. Ecol. Econ. 2019, 161, 100-108. [CrossRef]

29. Ting, H.; Fam, K.S.; Hwa, J.C.J.; Richard, J.E.; Xing, N. Ethnic food consumption intention at the touring destination: The national and regional perspectives using multi-group analysis. Tourism Manag. 2019, 71, 518-529. [CrossRef]

30. Singh, V.; Chauhan, S.C.; Tejyan, S. Greenhouse gas emission reduction potentials in air transport: A structural equation modelling-based multi-group analysis. Technol. Anal. Strateg. 2017, 29, 442-461. [CrossRef]

31. Wang, Z.H.; Guo, D.X.; Wang, X.M.; Zhang, B.; Wang, B. How does information publicity influence residents' behaviour intentions around e-waste recycling? Resour. Conserv. Recy. 2018, 133, 1-9. [CrossRef]

32. Khan, F.; Ahmed, W.; Najmi, A. Understanding consumers' behavior intentions towards dealing with the plastic waste: Perspective of a developing country. Resour. Conserv. Recy. 2019, 142, 49-58. [CrossRef]

33. Chu, K.M. Mediating influences of attitude on internal and external factors influencing consumers' intention to purchase organic foods in China. Sustainability 2018, 10, 4690. [CrossRef] 
34. Afroz, R.; Masud, M.M.; Akhtar, R.; Islam, M.A.; Duasa, J.B. Consumer purchase intention towards environmentally friendly vehicles: an empirical investigation in Kuala Lumpur, Malaysia. Environ. Sci. Pollut. R. 2015, 22, 16153-16163. [CrossRef] [PubMed]

35. Bandura, A. Self-efficacy mechanism in psychobiologic functioning. In Self Efficacy Though; Schwarzer, R., Ed.; Hemisphere: Washington, DC, USA, 1992; pp. 355-394.

36. Armitage, C.J.; Conner, M. Efficacy of the theory of planned behaviour: A meta-analytic review. Br. J. Clin. Psychol. 2001, 40, 471-499. [CrossRef] [PubMed]

37. Wang, P.; Liu, Q.; Qi, Y. Factors influencing sustainable consumption behaviors: A survey of the rural residents in China. J. Clean. Prod. 2014, 63, 152-165. [CrossRef]

38. Klöckner, C.A.; Blöbaum, A. A comprehensive action determination model: Toward a broader understanding of ecological behaviour using the example of travel mode choice. J. Environ. Psychol. 2010, 30, 574-586. [CrossRef]

39. Khare, A. Antecedents to green buying behaviour: A study on consumers in an emerging economy. Mark. Intell. Plan. 2015, 33, 309-329. [CrossRef]

40. Moser, A.K. Thinking green, buying green? Drivers of pro-environmental purchasing behavior. J. Consum. Mark. 2015, 32, 167-175.

41. Tsarenko, Y.; Ferraro, C.; Sands, S.; McLeod, C. Environmentally conscious consumption: The role of retailers and peers as external influences. J. Retail Consum. Serv. 2013, 20, 302-310. [CrossRef]

42. Fransson, N.; Gärling, T. Environmental concern: Conceptual definitions, measurement methods, and research findings. J. Environ. Psychol. 1999, 19, 369-382. [CrossRef]

43. Wakefield, S.E.; Elliott, S.J.; Eyles, J.D.; Cole, D.C. Taking environmental action: the role of local composition, context, and collective. Environ. Manage. 2006, 37, 40-53. [CrossRef]

44. Van Doorn, J.; Verhoef, P.C. Willingness to pay for organic products: Differences between virtue and vice foods. Int. J. Res. Mark. 2011, 28, 167-180. [CrossRef]

45. Hu, H.H.; Parsa, H.G.; Self, J. The dynamics of green restaurant patronage. Cornell Hosp. Q. 2010, 51, 344-362. [CrossRef]

46. Tobler, C.; Visschers, V.H.; Siegrist, M. Eating green consumers' willingness to adopt ecological food consumption behaviors. Appetite 2011, 57, 674-682. [CrossRef] [PubMed]

47. Teksoz, G.; Sahin, E.; Tekkaya-Oztekin, C. Modeling environmental literacy of university students. J. Sci. Educ. Technol. 2012, 21, 157-166. [CrossRef]

48. Hartmann, P.; Apaolaza-Ibáñez, V. Consumer attitude and purchase intention toward green energy brands: The roles of psychological benefits and environmental concern. J. Bus. Res. 2012, 65, 1254-1263. [CrossRef]

49. Conner, M.; Armitage, C.J. Extending the theory of planned behavior: A review and avenues for further research. J. Appl. Soc. Psychol. 1998, 28, 1429-1464. [CrossRef]

50. Chan, E.S.; Hawkins, R. Attitude towards EMSs in an international hotel: An exploratory case study. Int. J. Hosp. Manag. 2010, 29, 641-651. [CrossRef]

51. Joshi, Y.; Rahman, Z. Factors affecting green purchase behaviour and future research directions. Int. Strategic Manag. 2015, 3, 128-143. [CrossRef]

52. Chiu, C.M.; Hsu, M.H.; Lai, H.; Chang, C.M. Re-examining the influence of trust on online repeat purchase intention: The moderating role of habit and its antecedents. Decis. Support Syst. 2012, 53, 835-845. [CrossRef]

53. Moraes, C.; Carrigan, M.; Szmigin, I. The coherence of inconsistencies: Attitude-behaviour gaps and new consumption communities. J. Market. Manag. 2012, 28, 103-128. [CrossRef]

54. Busse, M.; Menzel, S. The role of perceived socio-spatial distance in adolescents' willingness to engage in pro-environmental behavior. J. Environ. Psychol. 2014, 40, 412-420. [CrossRef]

55. Hew, J.J.; Badaruddin, M.; Moorthy, M.K. Crafting a smartphone repurchase decision making process: Do crossMark brand attachment and gender matter? Telemat. Inform. 2017, 34, 34-56. [CrossRef]

56. Misic, K.U.; Podnar, K. Perception of city management, fellow residents, and Perceived External Prestige (PEP) as antecedents of city affective commitment - The city marketing perspective. Cities 2019, 84, 66-74. [CrossRef]

57. Menozzi, D.; Mora, C. Fruit consumption determinants among young adults in Italy: A case study. Lwt-Food Sci. Technol. 2012, 49, 298-304. [CrossRef]

58. Awuni, J.A.; Du, J.G. Sustainable consumption in chinese cities: Green purchasing intentions of young adults based on the theory of consumption values. Sustain. Dev. 2016, 24, 124-135. [CrossRef] 
59. Fornell, C.; Bookstein, F.L. Two structural equation models: LISREL and PLS applied to consumer exit-voice theory. J. Marketing Res. 1982, 19, 440-452. [CrossRef]

60. Calvo-Porral, C.; Faina-Medin, A.; Nieto-Mengotti, M. Satisfaction and switching intention in mobile services: Comparing lock-in and free contracts in the Spanish market. Telemat. Inform. 2017, 34, 717-729. [CrossRef]

61. Roy, S.K.; Balaji, M.S.; Soutar, G.; Lassar, W.M.; Roy, R. Customer engagement behavior in individualistic and collectivistic markets. J. Bus. Res. 2018, 86, 281-290. [CrossRef]

62. Oduro, S.; Haylemariam, L.G. Market orientation, CSR and financial and marketing performance in manufacturing firms in Ghana and Ethiopia. Sustain. Account. Mana. 2019, 10, 398-426. [CrossRef]

63. Prayag, G.; Lee, C. Tourist motivation and place attachment: the mediating effects of service interactions with hotel employees. J. Travel Tour. Mark. 2019, 36, 90-106. [CrossRef]

64. Lee, C.; Hallak, R. Investigating the moderating role of education on a structural model of restaurant performance using multi-group PLS-SEM analysis. J. Bus. Res. 2018, 88, 298-305. [CrossRef]

65. Cho, S.H.; Ali, F.; Manhas, P.S. Examining the impact of risk perceptions on intentions to travel by air: A comparison of full-service carriers and low-cost carriers. J. Air Transp. Manag. 2018, 71, 20-27. [CrossRef]

66. Teo, T.; Lee, C.B.; Chai, C.S.; Wong, S.L. Assessing the intention to use technology among pre-service teachers in Singapore and Malaysia: A multigroup invariance analysis of the Technology Acceptance Model (TAM). Hist. Comput. 2009, 53, 1000-1009. [CrossRef]

67. Tarhini, A.; Hone, K.; Liu, X.H. The effects of individual differences on e-learning users' behaviour in developing countries: A structural equation model. Comput. Human. Behav. 2014, 41, 153-163. [CrossRef]

68. Chen, H.K.; Yan, D.W. Interrelationships between influential factors and behavioral intention with regard to autonomous vehicles. Int. J. Sustain. Transp. 2019, 13, 511-527. [CrossRef]

69. Hair, J.F., Jr.; Hult, G.T.M.; Ringle, C.; Sarstedt, M. A Primer on Partial Least Squares Structural Equation Modeling (PLS-SEM), 2nd ed.; Sage Publications: Thousand Oaks, CA, USA, 2016.

70. Hair, J.F. Multivariate Data Analysis: A Global Perspective, 7th ed.; Pearson Education: Upper Saddle River, NJ, USA, 2010.

71. López-Navarro, M.Á.; Llorens-Monzonís, J.; Tortosa-Edo, V. Residents' behaviour as a function of cognitive appraisals and affective responses toward a petrochemical industrial complex. J. Clean. Prod. 2016, 112, 1645-1657. [CrossRef]

72. Sanchez-Prieto, J.C.; Olmos-Miguelanez, S.; Garcia-Penalvo, F.J. MLearning and pre-service teachers: An assessment of the behavioral intention using an expanded TAM model. Comput. Human. Behav. 2017, 72, 644-654. [CrossRef]

73. Chaouali, W.; Souiden, N. The role of cognitive age in explaining mobile banking resistance among elderly people. J. Retail Consum. Serv. 2019, 50,342-350. [CrossRef]

74. Chin, H.C.; Choong, W.W.; Alwi, S.R.W.; Mohammed, A.H. A PLS-MGA analysis of farming characteristics on the intentions of smallholder oil palm planters to collect palm residues for biofuel production. Biomass Bioenergy 2019, 120, 404-416. [CrossRef]

75. Matthews, L. Applying multigroup analysis in PLS-SEM: A step-by-step process. In Partial Least Squares Path Modeling; Latan, H., Noonan, R., Eds.; Springer: Cham, Switzerland, 2017; pp. 219-243.

76. Li, J.R.; Zuo, J.; Cai, H.; Zillante, G. Construction waste reduction behavior of contractor employees: An extended theory of planned behavior model approach. J. Clean. Prod. 2018, 172, 1399-1408. [CrossRef]

77. Wang, C.; Zhang, J.H.; Yu, P.; Hu, H. The theory of planned behavior as a model for understanding tourists' responsible environmental behaviors: The moderating role of environmental interpretations. J. Clean. Prod. 2018, 194, 425-434. [CrossRef]

78. Wang, C.; Zhang, J.H.; Cao, J.J.; Hu, H.; Yu, P. The influence of environmental background on tourists' environmentally responsible behaviour. J. Environ. Manag. 2019, 231, 804-810. [CrossRef] [PubMed]

79. Chan, E.S.W.; Hon, A.H.Y.; Chan, W.; Okumus, F. What drives employees' intentions to implement green practices in hotels? The role of knowledge, awareness, concern and ecological behaviour. Int. J. Hosp. Manag. 2014, 40, 20-28. 
80. Vainio, A.; Paloniemi, R. The complex role of attitudes toward science in pro-environmental consumption in the Nordic countries. Ecol. Econ. 2014, 108, 18-27. [CrossRef]

81. Hu, H.; Zhang, J.H.; Chu, G.; Yang, J.H.; Yu, P. Factors influencing tourists' litter management behavior in mountainous tourism areas in China. Waste Manag. 2018, 79, 273-286. [CrossRef] [PubMed]

(C) 2019 by the authors. Licensee MDPI, Basel, Switzerland. This article is an open access article distributed under the terms and conditions of the Creative Commons Attribution (CC BY) license (http://creativecommons.org/licenses/by/4.0/). 